
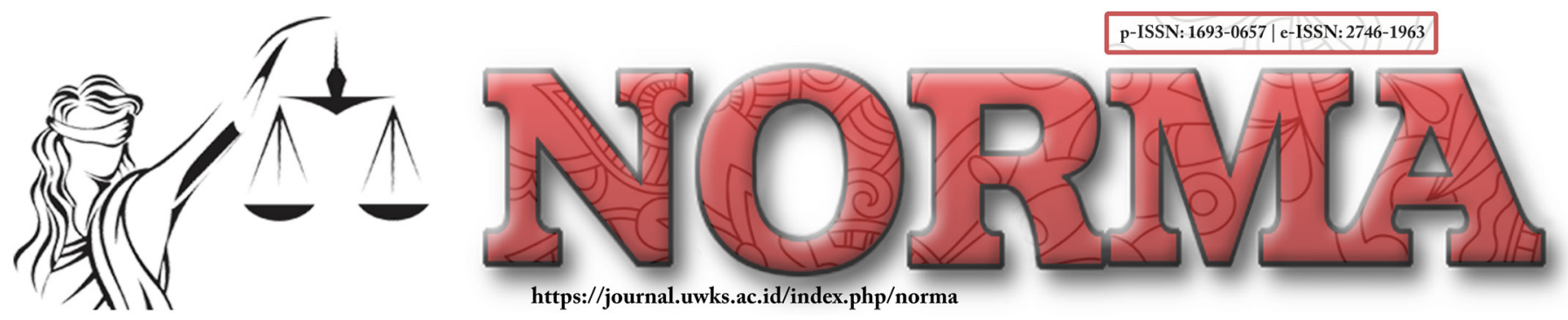

\title{
Liability Principles of PT. Perusahaan Listrik Negara (Persero) To the Loss of Consumers Electric Services
}

\author{
Riono \\ Law Faculty, Universitas Wijaya Kusuma Surabaya \\ e-Mail: esdm.riono@gmail.com
}

\begin{abstract}
:
Electricity is essential for our daily needs and community and businesses because it can run their products. Recently the community and we depend on electricity, so the usage of electricity is getting an increase. All our hardware and software tools use electricity because electricity changes our style in daily life. So, the management of electricity which the State gives to PT. Perusahaan Listrik Negara $(P L N)$ is a "State-Owned Enterprise" as we were known (BUMN). The electricity distributed to the consumers are still frequently blackout, therefore people and community fell loss with the outage, and make lawsuits to PT. PLN (Persero). This study uses a normative juridical approach, which analyzes data Referring to norms in the applicable law and regulations. The benefit of this research to contribute to the development of legal science, specifically the rule regarding consumer protection for electricity users. This research suggested that PT. PLN (Persero) commits to make a quick response when there is a blackout and give good service to the users. The consumers have to get a copy of the Power Purchase Agreement at the beginning of the installation. It is essential for the consumers as evidence to do a lawsuit when PT. PLN did not keep the promise of the Agreement.

Keywords: Electricity, Blackout, Lawsuits.
\end{abstract}

\author{
Article's History: \\ Received: \\ 6 November, 2020; \\ Received in revised form: \\ 8 February, 2021; \\ Accepted: \\ 8 February, 2021; \\ Published: \\ 9 February, 2021. \\ DOI: \\ 10.30742/nlj.v17i3.1073
}

\section{INTRODUCTION}

Electric power has a vital role in realizing national development goals. The supply effort needs to be continuously improved in line with development developments to be available in sufficient quantity, equality, and quality. Because electric power is a vehicle that plays a vital role in national development, electricity availability must be guaranteed to carry out its function as the national economy's driving force and backbone. Given the importance of electricity in public and industrial life, the supply of electricity is controlled by the State, as stated in the 1945 Constitution Article 33 Paragraph 2. PT. PLN currently carries out the distribution of electricity to the public as consumers of electricity. PT. PLN is a State-Owned Enterprise, based on Law Number 30 of 2009 concerning electricity, the main task of PT. PLN (Persero) is to carry out the business of providing electricity for the public interest. 
The issuance of Law Number 30 of 2009 concerning Electricity changed the status of PT. PLN (Persero), originally the Electricity Business Authority holder, became the Electricity Provider Business License Holder, and as a state-owned company, PT. PLN (Persero) has priority as the holder of a business license in the electricity sector.

To buy electricity from PT. PLN (Persero), which subscribes for the first time or has just subscribed, the consumer early signs a contract or Agreement called the Power Purchase Agreement (SPJBTL), and from the Agreement, the parties' rights and obligations arise. Based on the power purchase agreement between PT. PLN (Persero) and consumers stated that the distribution of electricity by PT. PLN (Persero) is implemented continuously without intermittent, except in the following cases:

1) Force majeure occurred including riots, war riots, strikes, fires, earthquakes, floods, landslides, volcanic eruptions, tsunamis, fallen trees, lightning, airplane accidents, theft of electric cables which resulted in the interruption of the distribution of electricity, the result there is a government regulation;

2) There is a temporary termination to the consumer installation as a follow-up to curbing the use of electricity at the consumer's premises, network maintenance activities and or network installation;

3) At times of peak loads, which from time to time, require a blackout by PT. PLN (Persero);

4) PT. PLN (Persero) carries out maintenance and or repair of power plants and or networks;

5) By order of the competent authority or court.

In Article 1233 Burgerlijk Wetboek (from now on referred to as BW), it states that "Every engagement is born good by agreement, either due to law" and Article 1320 BW there are four conditions to determine the validity of the Agreement, namely:

1) Agreeing to those who bind themselves;

2) The ability to make an engagement;

3) A specific thing and;

4) A cause that is allowed.

An agreement is an event that occurs when the parties promise each other to perform specific actions. According to the Subject of a contract is an occasion when one or more people promise to carry out an agreement or commit to each other to do something. ${ }^{1}$

In the Agreement, electricity consumers commit themselves to pay electricity bills and are entitled to electricity and/or electricity services, and PT. PLN (Persero) is obliged to provide electric power and electricity services to electricity consumers. PLN (Persero) has the right to receive payments in the form of a sum of money from consumers or electricity services users. If the electricity consumer is late paying for his electricity usage every month, a fine or 3 (three) consecutive months will be terminated.

1 Wawan Muhwan Hariri. (2011). Hukum Perikatan. Bandung: CV Pustaka Setia, p. 119 
One of the blackout events occurred on August 4, 2019, where electricity in the Banten, DKI Jakarta and West Java areas went out for between 8 hours and 18 hours because the system at SUTET Ungaran-Pemalang was blackout. The blackout resulted in losses for both household customers and small and medium industries. In-Law Number 30 of 2009 concerning Electricity, Article 29 paragraph (1) letter e, states that "consumers have the right to receive compensation in the event of an outage caused by errors and/or negligence in operation by the holder of the electricity supply business license according to the conditions specified. It was regulated in the power purchase agreement".

In-Law Number 8 of 1999 concerning Consumer Protection in Article 4 letter h, it is also stated that "consumers are entitled to compensation, compensation and/or replacement of the goods and/or services received are not under the agreement or not as they should be."

\section{PROBLEM FORMULATION}

Liability Principles of PT. Perusahaan Listrik Negara (Persero) To the Loss of Consumers Electric Services

\section{RESEARCH METHOD}

This study uses a normative juridical approach, which analyses data and refers to legal norms in the prevailing laws and regulations.

\section{DISCUSSION}

\section{The lawsuit against PT. PLN (Persero) based on Default}

Based on Article 1233 BW. It is emphasized that every civil obligation can occur because of the will of the parties involved in the engagement/agreement which they deliberately make, or because applicable laws and regulations determine it. Thus, it means that an engagement or Agreement is a legal relationship between two or more people (parties) in the field of assets, which creates an obligation on one of the parties in the legal connection. ${ }^{2}$ In Article 1320 BW there are four conditions to determine the validity of the Agreement. ${ }^{3}$

In the implementation of an agreement, the consequence is that all assets of a person or entity that is recognized as a legal entity will be at stake and used as a guarantee for each engagement or contract of the individual and/or legal entity, as described in Article 1131 BW. ${ }^{4}$

${ }^{2}$ Kartini Muljadi dan Gunawan Widjaja. (2003). Perikatan Pada Umumnya. Jakarta: PT. Raja Grafindo Persada, p. 17

${ }^{3}$ Ahmadi Miru. (2010). Hukum Kontrak Perancangan Kontrak. Jakarta: PT. Raja Grafindo, p.13

${ }^{4}$ Gunawan Widjaja dan Kartini Muljadi. (2003). Perikatan yang Lahir dari Undang-Undang. Jakarta: PT. Raja Grafindo Persada, p. 1 
One of the things done by PT. Before connecting electricity to electricity consumers, PLN must first sign a Power Purchase Agreement (SPJBTL). The Agreement made by the parties can be used as the basis for the engagement for both parties - rights and obligations of PT. PLN (Persero) is listed in Law Number 30 of 2009 concerning Electricity Article 27 and Article 28. It explains that the electricity supply business license holder's obligations are required to provide electricity that meets the applicable quality and reliability standards, providing the best possible service to consumers and society.

Then the electric power consumers, their rights and obligations are regulated in Law Number 30 of 2009 concerning Electricity Article 29 paragraph (1) and paragraph (2). One of the rights of electricity users themselves is to receive electricity continuously with good quality and reliability, to receive compensation if a blackout occurs due to errors and/or negligence in operation by the holder of the electricity supply business license according to the conditions stipulated in the Agreement. Buying and selling of electricity. Meanwhile, electricity user consumers must pay electric power usage bills, which of course must be done to get electricity supply in each consumer's house.

Law Number 8 the Year 1999 regarding Consumer Protection Article 7 letter $g$ states that business actors are required to provide compensation, compensation and/or replacement of the goods and/or services received or used are not under the Agreement.

Power outages by PT. PLN (Persero) is very detrimental to electricity consumers because it is disrupted in its activities. With the blackout that was not informed beforehand, PT. PLN (Persero) violates the Agreement agreed upon so that the electricity consumer is entitled to compensation or compensation caused by the outage. In the event of a unilateral blackout, then one of the obligations of PT. PLN (Persero) provides the best possible service to consumers and society. It can be said that it is not appropriately implemented under what PT. PLN (Persero). So, in this case, PT. PLN (Persero) as a debtor, broken promises (Default) in fulfilling its obligations to creditors (consumers using electricity).

In the case of a request for compensation, the consumer can file lawsuit at the local District Court to PT. PLN (Persero). But of corse, before that, we all should try to resolve problem with good faith amicably and peacefully. If PT. PLN doesn't respond, then consumer may use the litigation method. Sadly, even if the consumer's lawsuit against PT. PLN (Persero) is granted by the judge, the judge decision will be nonexecutable. This is because of PT. PLN (Persero) is a state-owned company which incidentally belongs to the government. Confiscation of guarantees and confiscation of execution of state property is prohibited, wherein Article 50 of Law Number 1 of 2004 concerning State Treasury it is stated that any party is not permitted from confiscating:

1) Goods or securities belonging to the state/region, either in government agencies or in third parties; 
2) Money that must be deposited by a third party to the country/region;

3) Movable property belonging to the state/region, either in government agencies or by third parties;

4) Movable property and other things belong to the state/region;

5) Goods belonging to third parties paid by the state/region.

Therefore, Default cannot recover the losses of electricity consumers who experience blackouts.

\section{Class-Action against PT. PLN (Persero)}

There are other regulations governing compensation in the event of a blackout. Regulated in the Minister of Energy and Mineral Resources Regulation Number 18 of 2019 concerning the Second Amendment to the Regulation of the Minister of Energy and Mineral Resources Number 27 of 2017 concerning Service Quality Levels and Costs Associated with the Distribution of Electric Power by PT. PLN (Persero).

A class action can be used in filing a lawsuit by consumers who are not satisfied with PT. PLN (Persero). The blackout conducted by PT. PLN (Persero) without prior notification or even delay in delivering information, can cause consumer losses. Consumer losses are diverse, ranging from disruption of activities and comfort, especially for urban people who prioritize all electronic equipment, to the death of domestic ornamental fish such as koi and arwana. The blackout is very detrimental to many people. If it is to file a lawsuit if each electricity consumer carries it out, it is not sufficient and efficient. It will be carried out in a class representative suit.

Article 46 paragraph (1) letter b of Law No. 8 of 1999 concerning Consumer Protection, describes an effort to resolve consumer disputes, namely by lawsuits: Lawsuits against business actors' violations can be filed by a group of consumers who have the same interest. The lawsuit referred to in Article 46 paragraph (1) letter $b$ is referred to as a class-action lawsuit. There are several elements related to the class action lawsuit, among others:

1) Civil litigation, namely a class action lawsuit, entered into the field of civil law. The term lawsuit is known in civil procedural law as an action that aims to obtain the protection of the rights provided by the court to avoid eigenechting;

2) Class Representative, namely one or more people who suffer losses who file a lawsuit simultaneously, represents many people. To become a group representative is not required to have an extraordinary power of attorney from a group member. When a class action lawsuit is filed in court, the position of the group representative is as active plaintiff;

3) Class members, namely a group of people in large numbers who suffer losses whose interests are represented by group representatives in court. If the class action is submitted to the court, the position of the group member is as a passive plaintiff; 
4) There is a loss, namely, to submit a class action, both group representatives (class representative) and group members (class members) must actually or experience losses or are termed concrete injured parties;

5) The similarity of events or facts and legal basis, namely there are similarities in points (events) and likeness of the legal basis (a question of law) between the party representing (class representative) and the party designated (class members).

To file a lawsuit through a class action, several requirements must be met, including:

1) There are a large number of members (numerosity); namely, the number of class members must be so much that it is not sufficient and efficient if the lawsuit is carried out individually;

2) There is commonality, that is, there are similarities in facts (events) and likeness of the legal basis (a question of law) between the party that is represented (class representative) and the party designated (class members);

3) Similar (typically), namely the demands and defence of all members represented must be the same as those expressed;

4) Adequacy of representation that is, group representatives must have honesty and seriousness to protect the group members' interests being represented. The party who will be the class representative must meet several requirements to determine his suitability in filing a court lawsuit. Some of these requirements include:

a) Has the same fact or legal basis with the group represented;

b) Have strong evidence that can be justified;

c) Have integrity and be accountable for their statements and actions before the law;

d) Committed to fighting for the rights of the group it represents for the losses caused by the defendant;

e) Putting the interests of groups over personal interests;

f) Willing and able to bear the costs required during the process of filing a lawsuit and trial.

Based on the provisions of Article 1 letter (b) of Perma No. 1 of 2002 concerning Class Action Program, it is determined that the group representative is one or more people who suffer losses who file a lawsuit and at the same time represent a larger group of people (group members).

Apart from themselves, class representative action is a procedure for filing a lawsuit, in which one or more people representing the group file a lawsuit for themselves or at the same time represent a large group of people, who have the same fact or legal basis between the representatives. Thus, a party who does not suffer a loss cannot file a lawsuit as a representative. ${ }^{5}$

${ }^{5}$ Sundari. (2002). Pengajuan Gugatan Secara Class action (Suatu Studi Perbandingan dan Penerapannya di Indonesia). Yogyakarta: Universitas Atma Jaya, p. 28 
In Article 46 paragraph (1) letter b of Law Number 8 the Year 1999 concerning Consumer Protection, it is stated that a group of consumers who have the same interests and facts can file a class action lawsuit against business actors. The similarity of interests and facts can be seen from the existence of the same agreements or evidence.

Parties that can file a class action lawsuit are only a group of people who have the same interests and facts, as explained in Article 46 paragraph (1) of the Consumer Protection Law that class action or class action must be filed by consumers who really can be proven legally, one of which is evidence of a Power Purchase Agreement (SPJBTL). Some of the benefits of a class-action lawsuit, namely:

1) A class action is useful because the litigation process becomes very economical (judicial economy). With class action lawsuit raising (repetition), similar claims individually can be prevented. It is not economical for a court to have to serve similar requests separately. The economic benefits are not only felt by the plaintiff but also by the defendant because with the class action the defendant only incurs a one-time fee to serve the claims of the aggrieved parties;

2) Class action provides access to justice. When a lawsuit is filed individually, it will result in burdens for potential plaintiffs, and often such limitations become an obstacle for someone to fight for their rights in court. Through the class action procedure, this constraint can be overcome by joining forces with other class members in one lawsuit, namely a class action lawsuit;

3) Class action is intended to change theattitude of the offender (behavior modification). The class action procedure application means providing more comprehensive access for justice seekers to file claims at a more efficient cost (cost efficiency). Thus, access to class action has the opportunity to encourage a change in the attitude of those who have the potential to harm the interests of the wider community. This kind of opportunity is called the opportunity to develop a deterrent effect;

4) Time, cost and energy savings, because the lawsuit is not filed by every member of the community or group, but is accumulated in one lawsuit. The value of empowering community members to achieve justice is that they do not fight alone but with other community members. ${ }^{6}$

Beside the benefit, there are also several obstacles in filing and implementing classaction lawsuit, namely: ${ }^{7}$

1) Difficulty in managing. The greater the number of group members, the more difficult it is to manage a class action lawsuit. The problems that occur are usually at the time of notification and distribution of compensation. Many group members

\footnotetext{
${ }^{6}$ Hotma Timbul Hutapea. (2001). Class Action Konsumen Elpiji, Upaya memperjuangkan Hak dan Ganti Rugi. Makalah disampaikan dalam Forum Dialog Konsumen Elpiji di Hotel Wisata Internasional, Jakarta, p. 5

7 Aulia Mutiah. (2018). Hukum Perlindungan Konsumen (Dimensi Hukum Positif dan Ekonomi Syariah). Yogyakarta: Pustaka Baru, p. 222
} 
and spreading in different areas will make it challenging to notify and require a lot of money. If the claim is won and compensation is given, it is possible that the amount of payment is not proportional to the cost of distribution;

2) Can cause injustice. This injustice is related to determining group membership and the binding power of the judge's decision. If the procedure chosen to determine group membership is an option in then the absence of statements from group members who have the same interests only because they are not aware of the notification, will result in the loss of their right to enjoy the success of a class-action lawsuit because the judge's decision will only have consequences. For those who enter as group members;

3) Can lead to the bankruptcy of the defendant. The number of claims for compensation in a class-action lawsuit can result in the defendant going bankrupt if the lawsuit is granted, where the defendant is obliged to provide payment or take specific actions to all the group members, which are very large in number;

4) The publication of a class-action lawsuit could corner the defendant. Mass media coverage and notification of class action suits in the mass media can be an attack on the defendant's position power. Usually, media readers will have wrong prejudices. It is not sure that the defendant is the guilty party because whether the defendant is right or not has yet to be proven by the court.

\section{CLOSING}

\section{Conclusion}

For those who loss, should try to resolve problem with good faith amicably and peacefully. Lawsuit against PT. PLN (Persero) based on Default even though it was granted and decided by the judge, does not necessarily mean PT. PLN (Persero) assets can be executed, since it is a state-owned enterprise which the government owns, so collateral seizure and execution cannot be carried out. Still, electricity consumers can only be compensated for the blackout, so the compensation lawsuit's decision automatically cannot recover consumer losses. Filing of a case can be done in a group (class action) because consumers who are disadvantaged by the blackout are many. so that it becomes ineffective and inefficient if they file a lawsuit individually.

\section{Recommendation}

PT. PLN (Persero) must provide information on the level of service quality to consumers in an open manner, and increase the speed of repairs in the event of a power cut and provide information to customers regarding power outages. PT. PLN (Persero electricity consumers should ask for a copy of Electricity Sale and Purchase Agreement (SPBJTL) at the initial electric power installation, since it can be useful when consumer feel disadvantaged or loss. 


\section{REFERENCES}

Burgerlijk Wetboek

Undang-Undang No. 30 Tahun 2009 Tentang Ketenagalistrikan

Undang-Undang No. 8 tahun 1999 Tentang Perlindungan Konsumen

Peraturan Mahkamah Agung Nomor 1 Tahun 2002 tanggal 26 April 2002 tentang Acara Gugatan Perwakilan Kelompok

Ahmadi Miru. (2010). Hukum Kontrak Perancangan Kontrak. Jakarta: PT.Raja Grafindo Persada.

Aulia Mutiah. (2018). Hukum Perlindungan Konsumen (Dimensi Hukum Positif dan Ekonomi Syariah). Yogyakarta: Pustaka Baru.

Gunawan Widjaja dan Kartini Muljadi. (2003). Perikatan yang Lahir dari Undang-Undang. Jakarta: PT. Raja Grafindo Persada.

Hotma Timbul Hutapea. (2001). Class Action Konsumen Elpiji, Upaya memperjuangkan Hak dan Ganti Rugi. Makalah disampaikan dalam Forum Dialog Konsumen Elpiji di Hotel Wisata Internasional. Jakarta.

Kartini Muljadi dan Gunawan Widjaja. (2003). Perikatan Pada Umumnya. Jakarta: PT. Raja Grafindo Persada.

Sundari. (2002). Pengajuan Gugatan Secara Class action (Suatu Studi Perbandingan dan Penerapannya di Indonesia). Yogyakarta: Universitas Atma Jaya.

Wawan Muhwan Hariri. (2011). Hukum Perikatan. Bandung: CV Pustaka Setia. 